https:/ / doi.org/10.18485/iipe_nsail.2020.ch4

\author{
Dragoljub TODIĆ1
}

\title{
NEDRŽAVNI AKTERI I UPRAVLJANJE ZAŠTITOM ŽIVOTNE SREDINE
}

\begin{abstract}
Apstrakt: $\mathrm{U}$ radu se polazi od (u literaturi) preovlađujućeg stava da postoji tendencija rastućeg uticaja tzv. nedržavanih aktera (NDA) u kreiranju i sprovođenju savremene politike i prava u oblasti životne sredine. Skreće se pažnja na izvesne metodološke dileme, uključujući i otvorena pitanja u vezi sa definisanjem pojma ",nedržavni akteri“" Pitanje uloge i položaja NDA sagledava se kroz analizu mesta nevladinih organizacija u najznačajnijim međunarodnim ugovorima u oblasti životne sredine globalnog i regionalnog karaktera koji su, istovremeno, od značaja za Republiku Srbiju (RS). Jednim od ključnih elemenata za procenu uloge NDA uzima se mogućnost učešća u procesu donošenja odluka. Analiziraju se norme sadržane u relevantnim međunrodnim ugovorima kojima se reguliše pristup informacijama i učešće javnosti u odlučivanju u oblasti životne sredine, u skladu sa Arhuskom konvencijom o dostupnosti informacija, učešću javnosti u odlučivanju i dostupnosti pravde $u$ pitanjima koja se tiču životne sredine. U radu se razmatra stav da su položaj i uloga NDA (kroz položaj i ulogu nevladinih organizacija) regulisani međunarodnim ugovorima u oblasti životne sredine samo do izvesne mere, na neujednačen i neprecizan način. To može da bude od uticaja na efikasnost upravljanja u oblasti životne sredine i zahteva dodatno preispitivanje procena o sve većem uticaju NDA.

Ključne reči: nedržavni akteri, nevladine organizacije, životna sredina, klimatske promene, međunarodni ugovori, Arhuska konvencija, javnost, pristup informacijama.
\end{abstract}

\footnotetext{
${ }^{1}$ Institut za međunarodnu politiku i privredu, Beograd, e-mail: dtodic@ymail.com.

Rad je nastao u okviru naučnoistraživačkog projekta "Srbija i izazovi u međunarodnim odnosima 2020. godine", koji finansira Ministarstvo prosvete, nauke i tehnološkog razvoja Republike Srbije, a realizuje Institut za međunarodnu politiku i privredu tokom 2020. godine.
} 


\section{UVOD I METODOLOŠKI OKVIR}

A) Izgleda da bi se moglo konstatovati da u literaturi postoji preovlađujuća saglasnost o tome da različiti subjekti koji nisu države imaju sve značajniju ulogu u međunarodnim odnosima, uključujući i aktivnosti koje se odnose na oblast životne sredine. U osnovi tvrdnje o povećanoj moći tzv. nedržavnih aktera (NDA) u savremenim međunarodnim odnosima, uključujući i oblast životne sredine leže različita teorijska objašnjenja i, delimično, empirijska istraživanja. ${ }^{2} U$ nekim raspravama se naglašava postojanje „istraživačkog jaza u vezi sa uticajem NDA na ulogu nacionalne države i UN u globalnoj politici u oblasti životne sredine". ${ }^{3}$ Raspravlja se i o različitim formama, sadržini i manifestacijama povećanog uticaja NDA. Bajermen (Biermann) i Pabrg (Pattberg), govoreći o "globalnom upravljanju”, konstatuju ne samo porast broja već i "sposobnosti nedržavnih aktera da učestvuju u upravljanju političkim sistemom."4 Pozivajući se na druge autore Sending (Sending) konstatuje da "države više ne mogu zaobići stavove

${ }^{2}$ U ovom radu se (u srpskoj verziji) koristi izraz „nedržavni akteri” za prevod engleske formulacije "non-state actors", iako bi se o ovom pitanju moglo raspravljati. Za više opštih informacija u vezi sa rastućim značajem NDA videti, npr: Andrew Heiss, Tana Johnson, "Internal, Interactive, and Institutional Factors: A Unified Framework for Understanding International Nongovernmental Organizations", International Studies Review, Vol. 18, No. 3, September 2016, pp. 528-541; Ole Jacob Sending, Iver B. Neumann, “Governance to Governmentality: Analyzing NGOs, States, and Power", International Studies Quarterly, Vol. 50, No.3, September 2006, pp. 651-672. Nathan Alexander Sears, "International Politics in the Age of Existential Threats", Journal of Global Security Studies, 0(0), 2020, pp. 123, doi: 10.1093/jogss/ogaa02. Neki autori ukazuju i na "precenjivanje” uloge „privatnih subjekata” u međunarodnim odnosima. Videti: Charles Roger and Peter Dauvergne, "The Rise of Transnational Governance as a Field of Study", International Studies Review, Vol. 18, 2016, p. 417.

${ }^{3}$ Za šire videti: Joseph S. Weiss, Zhu Dajian, Maria Amélia Enríquez, Peter H. May, Elimar Pinheiro do Nascimento, Walter A. Pengue, Stanislav Schmele, "UN environmental policy: Non-State Actors, trends, and the regulatory role of the state", Journal of Political Ecology Vol. 24, 2017, pp. 1013-1037. Moguće je da bi se o istraživačkom jazu moglo govoriti i kada se raspravlja o formama uticaja NDA.

${ }^{4}$ Frank Biermann and Philipp Pattberg, "Global Environmental Governance: Taking Stock, Moving Forward", Annu. Rev. Environ. Resour, Vol. 33, 2008, p. 280. 
transnacionalnih aktera”, jer su oni „ojačali svoj pregovarački položaj značajnim moralnim, finansijskim i resursima znanja". ${ }^{5}$ Kejler (Kahler) polazi od stava da su u periodu nakon hladnog rata dva snažna subjekta podržavali procese koji su išli u pravcu "globalne uprave": multinacionalne korporacije (koje su imale koristi od otvorene međunarodne privrede i trgovinskih i investicioni hsporazuma koji su podržavali kompanije) kao i nevladine organizacije (koje deluju preko nacionalnih granica globalnim planovima u oblasti ljudskih prava, klime, globalnog zdravlja itd). ${ }^{6} \mathrm{U}$ gotovo svim oblastima međunarodnog prava naglašava se važnost nedržavnih aktera i učesnika "subdržavnog" karaktera kako u suvremenom normativnom razvoju, tako i u tumačenju i primeni normi. Međunarodno pravo sve više karakteriše transnacionalni pravni proces evolucije $u$ kojem civilno društvo i drugi doprinose artikulaciji prava na nacionalnom, regionalnom i međunarodnom nivou. ${ }^{7}$

B) Ipak, nekoliko je prethodnih pitanja koja bi trebalo imati u vidu. Pitanje subjektiviteta u međunarodnom pravu se postavlja kao jedno do takvih. Lapaš konstatuje da ovo pitanje ni $u$ jednoj grani prava nije zadržalo aktuelnost $u$ onoj mjeri $u$ kojoj to nalazimo $u$ međunarodnom pravu. ${ }^{8}$ Razloge takvog stanja on vidi u nekoliko činilaca pri čemu se glavni razlog pripisuje "prirodi samog međunarodnog prava". 9 Podsećajući na postojanje primenjivih prava i obaveza kao opšteg polazišta za procenu postojana „pravnog lica” Shaw (Šo) ukazuje na

${ }^{5}$ Ole Jacob Sending, Iver B. Neumann, op. cit. p. 654

${ }^{6}$ Miles Kahler, "Global Governance: Three Futures", International Studies Review, Vol. 20, 2018, pp. 239-246, doi: 10.1093/isr/viy035

${ }^{7}$ Cecilia Bailliet (Ed), Non-state actors, soft law, and protective regimes: from the margins, Cambridge University Press 2012, p. 6.

${ }^{8}$ Davorin Lapaš, "Non-governmental entities on the doorstep of 'subjectivity' in international law - A path to new international law?", Zbornik Pravnog Fakulteta u Zagrebu, Vol. 62, No. 5-6, 2012, p. 1759.

9 "Njegova horizontalna, nehijerarhijska struktura, nedostatak 'zakonodavca' u smislu unutrašnjih pravnih poredaka, a time i specifičnost procesa nastanka međunarodnopravnih normi čine vezu doktrine i prakse međunarodnog prava intenzivnijom i neposrednijom nego u bilo kojoj drugoj pravnoj grani ....", Ibid, 1759. 
dileme i dva krajnja gledišta u raspravama o pravnom subjektivitetu $\mathrm{u}$ međunarodnom pravu. ${ }^{10}$ Autor naglašava da bi trebalo pažljivo ispitati niz faktora pre nego što se utvrdi da li subjekat ima međunarodni „personalitet” i, ako je tako, koja se prava, dužnosti, pravila o nadležnosti, itd. primenjuju u konkretnom slučaju. Jednom od karakteristika savremenog međunarodnog prava proglašava se postojanje šireg kruga „učesnika” („participants”) koji uključuje države, međunarodne organizacije, regionalne organizacije, nevladine organizacije, javna preduzeća, privatne kompanije i pojedince. ${ }^{11}$ Ipak, to ne znači da će svi takvi subjekti imati svojstvo pravnog lica, iako mogu delovati sa određenim stepenom uticaja na međunarodnom planu. „Međunarodni personalitet je učešće plus neki oblik prihvatanja u zajednici." ${ }^{12}$

Iako su u teoriji definisani opšti kriterijumi, u zavisnosti od pristupa, subjektivitet $u$ međunarodnom pravu se priznaje državama i priznaje (ili osporava) nekim drugim entitetima. Tako na primer, Lindblm (Lindblom) pod subjektima međunarodnog prava podrazumeva države, međunarodne organizacije i institucije koje imaju pravni kapacitet da deluju u međunarodnim odnosima, te organizovane grupe ili korporativni subjekti raznih vrsta, čiju pravnu sposobnost za učestvovanje u pravnim odnosima priznaju države. ${ }^{13}$ Elkbi (Alkoby)

${ }^{10}$ Malcolm N. Shaw, International Law, Fifth edition, Cmabridge University Press, Cambridge, 2003, p. 176.

${ }^{11} \mathrm{Ibid}, \mathrm{p} .176$. Ovom spisku „učesnika” autor je u novijem izdanju knjige dodao i "grupe angažovane u međunarodnom terorizmu." Malcolm M. Shaw, International Law, Seventh edition, Cambridge University Press, Cambridge, 2014, p. 143.

${ }^{12}$ Poslednji element zavisi od različitih faktora, uključujući vrstu ličnosti o kojoj je reč. On se može manifestovati u više oblika, a u određenim slučajevima se može izvesti iz prakse i odražavati potrebe. Određene grane međunarodnog prava imaju ključnu ulogu. Pravo ljudskih prava, pravo oružanih sukoba i međunarodno privredno pravo posebno su važni u stvaranju i odražavanju olakšanog učešća u međunarodnom pravu. Ibid, p. 177.

${ }^{13}$ Anna-Karin Lindblom, Non-Governmental Organisations in International Law, Cambridge University Press, 2005, p. 88. Zajednički imenitelj svih subjekata međunarodnog prava je kvalitet delovanja sa pravnim kapacitetom. Za šire o pitanju da li su korporacije subjekti međunarodnog prava videti kod: Jose E. Alvarez, "Are Corporations Subjects of International Law", Santa Clara Journal of International Law, Vol. 9, No. 1, 2011, pp. 1-36. 
postavlja nekoliko pitanja za koja smatra da bi trebalo da pomognu u traganju za odgovorima na pitanje pravnog subjektiviteta "nedržavnih aktera”, uključujući i pitanje definicije „nevladinih organizacija” i njihove uloge u postojećim institucionalnim aranžmanima. ${ }^{14}$

C) U literaturi pitanje definicije pojma NDA nije u razjašnjeno. Kod nekih autora se određenje sadržaja ovog pojma zasniva na definisanim elementima onoga što se obično razume kao deo subjektiviteta "država” u međunarodnom pravu. ${ }^{15}$ Ostavljajući ovde po strani teorijske aspekte rasprave, konkretniji pokušaji definisanja pojma NDA zasnovani su više na tehničkim kriterijumima i nabrajanju subjekata za koje bi se moglo smatrati da ulaze u okvir onoga što podrazumeva ovaj pojam. U tom smislu, značajan broj autora je saglasan oko toga koji bi se subjekti mogli da smatraju NDA, ali su ne zanemarljive razllike $u$ nekim specifičnim elementima. Tako, na primer, kada govori o NDA Rinalda (Reinalda) govori o tri vrste subjekata: nevladine organizacije, međuvladine organizacije i transnacionalne korporacije. ${ }^{16}$ Slično i kod Jolića. ${ }^{17}$ Za Runit (Ronit) i Šnajder (Schneider) kategorija NDA „,iako uključuje nevladine organizacije, zamišljena je da obuhvati veći broj različitih subjekata poput multinacionalnih preduzeća, kartela i kriminalnih, verskih i etničkih mreža. Neki od njih se nikada, ili retko, tretiraju kao nevladine organizacije." Istovremeno, ukazuje se i na to da je "koncept" NDA problematičan i u meri u kojoj se pojam "nedržavni” preklapa sa "privatnim”, ali nije „privatni”. Ovaj pojam može obuhvatati i subjekte koji imaju javna olvašćenja ispod ili iznad nivoa države kao što su npr. opštine, nadnacionalne strukture i međuvladine organizacije."18 U vezi sa

${ }^{14}$ Asher Alkoby, "Non-State Actors and the legitimacy of international environmental law", Non-State Actors and International Law 3, 2003, pp. 29-50.

${ }^{15}$ Za šire videti: Clive Parry, Barker, J. C., \& Grant, J. P., Parry and Grant Encyclopaedic Dictionary of International Law (Vol. 3rd ed), Oxford: Oxford University Press, 2009, p. 584 .

${ }^{16}$ Bob Reinalda, (Ed), The Ashgate Research Companion to Non-State Actors, Ashgate,UK, 2011, p. 3.

${ }^{17}$ Tvrtko Jolić, „Nedržavni akteri i etika međunarodnih odnosa”, Drustvena Istrazivanja, Vol. 28, No. 4, 2019, pp. 711-729.

${ }^{18}$ Karsten Ronit, Volker Schneider (Eds), Private Organisations in Global Politics. Routledge, 2000, p. 11. 
NDA ponekad se govori i o tzv. „transnacionalnim akterima”. Trhel (Terhalle), uz upućivanje na druge autore, "transnacionalne aktere" definiše „,kao privatne aktere, koji deluju na profitnoj ili neprofitnoj osnovi u odnosu na međunarodne institucije. Za njih se uveliko čini da uključuju nevladine organizacije, multinacionalne korporacije, filantropske fondacije i naučne zajednice. Obično međunarodne institucije zapošljavaju „transnacionalne aktere" za poslove koji se odnose na nadzor poštovanja zakona, zatim predstavnike zainteresovanih strana, pružaoce usluga i stručnjake za politiku. ${ }^{19} \mathrm{U}$ vezi sa "nevladinim organizacijama” pitanje definicije „međunarodnih nevladinih organizacija” , za razliku od onih koji imaju nacionalni karakter, takođe, može biti relevantno. ${ }^{20}$ Odsustvo definicije "nevladinih organizacija" u međunarodnom pravu daje prostora za samostalne konstrukcije značenja ovog pojma. ${ }^{21}$ Bnari (Ben-Ari) ukazuje na to da neki pravnici smatraju da opšte međunarodno pravo ne definiše „međunarodne nevladine organizacije”. Autor se poziva Ricengrga (Rechengerga) koji sugeriše da su to „privatne organizacije (udruženja, federacije, sindikati, instituti, grupe) koje nisu osnovane od strane vlada ili na osnovu međuvladinih sporazuma, ali su sposobne da igraju ulogu $u$ međunarodnim poslovima zahvaljujući svojim aktivnostima čiji članovi imaju nezavisna glasačka prava."22

D) Slično kao i u drugim oblastima, tendencija jačanja uticaja tzv. NDA na različita pitanja koja se u stručnoj literaturi označavaju pojmom „,̌̌ivotna

${ }^{19}$ Maximilian Terhalle, "Transnational Actors and Great Powers during Order Transition", International Studies Perspectives, Vol. 17, No. 3, 2016, pp. 287-306.

${ }^{20}$ Ovo bez obzira što Arhuska konvencija (o čemu će kasnije biti više reči), imajući u vidu predmet svog reglisanja i način kako to čini, poušava da ovo pitanje učini sekundardnim. Ostaje da se s pravom može postaviti pitanje kada jedna organizacija koje registrovana u nekoj državi u skladu sa propisima te države postaje "akter" u međunarodnim odnosima, tj. šta bi moglo da je učini "međunarodnim u smislu prava i obaveza."

${ }^{21}$ Katherine Dick, "Exploring the Legal Status of Non-Governmental Organisations under International Energy Treaties", International Community Law Review, Vol. 10, 2008, p. 228.

${ }^{22}$ Rephael Harel Ben-Ari, The Normative Position of International Non-Governmental Organizations under International Law, An Analytical Framework, Martinus Nijhoff, Publishers, Leiden, Boston, 2012, p. 47. 
sredina", ne dovodi se u pitanje. ${ }^{23}$ Izgleda da porast značaja i uloge NDA na neki način i do izvesne mere korespondira i sa rastućim značajem problema u oblasti životne sredine, ili problema koji se najčešće povezuju sa „životnom sredinom", odnosno koji se percipiraju u javnosti na takav način. ${ }^{24}$ Tako se i pitanje uloge NDA čiji predmet delovanja obuhvata neka od pitanja koja se odnose na probleme u oblasti životne sredine ponekad razume kao neka vrsta "prirodnog procesa." ${ }^{25} \mathrm{Uz}$ istovremeno ukazivanje na potrebu da se ova činjenica ne bi smela ignorisati, obično se razmatraju različiti argumenti kojima se rastuća uloga NDA obrazlaže na afirmativan i/ili kritički način. ${ }^{26}$ Nesiritisi (Nasiritousi), et al, prihvatajući stav o rastućoj ulozi NDA ukazuju na neka metodološka pitanja i slabosti u istraživanju uloge NDA (nedostatak okvira da se razume zašto različiti akteri mogu imati komparativnu prednost u različitim fazama političkog spektra, šta utiče da pojedini NDA imaju autoritativnu ulogu u aktivnostima koje sprovode, a drugi ne, itd). ${ }^{27}$

${ }^{23}$ Videti, npr. Kal Raustiala, "States, NGOs, and International Environmental Institutions", International Studies Quarterly, Vol. 41, No. 4, December 1997, pp. 719-740. Izgleda da je ovaj pojam prvi put korišten u Sporazumu iz Cotonoua od 13. juna 2000. između Evropske zajednice i 79 država (afričke, karipske i pacifičke države). U članu 4 je prepoznata uloga i potencijal nedržavnih subjekata $u$ razvojnom procesu. U tom kontekstu, i u skladu sa onim kako se danas ovaj izraz uopšteno koristi u međunarodnom pravu i međunarodnim odnosima, može se reći da on ,jasno obuhvata nevladine organizacije i druge aspekte civilnog društva. Međutim, i neke se uloge tzv. NDA u međunarodnim aktivnostima (i međunarodnom pravu) mogu prepoznati u multinacionalnim korporacijama, oružanim bandama, terorističkim i grupama koje se bave organizovanim kriminalom." Autori zbog „nejasnoće pojma, njegovih sastavnih delova i posledica toga" sugerišu, da je verovatno bolje ovaj pojam "ograničiti na nevladine organizacije i civilno društvo." Parry, Clive, Barker, J. C., \& Grant, J. P. Parry and Grant Encyclopaedic Dictionary of International Law. op. cit, p. 420.

${ }^{24}$ Ovo pitanje bi moglo biti predmet posebno istraživanja.

${ }^{25}$ Kal Raustiala, op. cit. pp. 719-740.

${ }^{26}$ Eduardo Szazi, NGOs: Legitimate Subjects of International Law, Leiden University Press, 2012, p. 25. i dalje. Ovo nas ponovo vraća na metodološke aspekte rasprave o „moći” NDA.

${ }^{27}$ Naghmeh Nasiritousi, Mattias Hjerpe, Bjo“"rn-Ola Linne'r, “The roles of non-state actors in climate change governance: understanding agency through governance profiles", Int Environ Agreements, Vol. 16, No. 1, 2016, pp. 111, i dalje. 
Pitanje definicije pojma NDA u kontekstu upravljanja zaštitom životne sredine trebalo bi tumačiti uz uvažavanje izvesnih specifičnosti problema životne sredine kao predmeta međunarodne saradnje. To bi u detaljnijoj analizi moglo podrazumevati neophodnost da se najpre jasnije odredbi šta se podrazumeva pod pojmom „životna sredina", naročito u okolnostima kada postoji preklapanje sa drugim sadržajima koji utiču ili mogu da utiču na stanje životne sredine i obrnuto. ${ }^{28}$ Vaneselt (Van Asselt), za potrebe svog istraživanja pod pojmom NDA, obuhvata ne samo civilno društvo, poslovni sektor i istraživačke organizacije, već i podnacionalne vlasti, koji mogu da igraju različite uloge $u$ kreiranju i primeni međunarodnog prava $u$ oblasti životne sredine. ${ }^{29}$ Kajpr (Kuyper), et. al, u svojoj analizi, kada govori o NDA u okviru Pariskog sporazuma o klimi, spominje sledeće kategorije: „nevladine organizacije (NVO), poslovne grupe, istraživačke centre, sindikate, privatne aranžmane upravljanja, transnacionalne mreže i nivoe vlasti ispod nacionalnog. " 30 Grin (Green) definiše NDA tako što, ,"indikativno" u ovaj pojam „uključuje nevladine organizacije, privredne subjekte i transnacionalne mreže, kao i naučna i druga stručna tela". Na taj način, autor u ovaj pojam „uključuje sve aktere koji nisu ni države niti međunarodne organizacije." ${ }^{31} \mathrm{Hel}$ (Held) i Rodžer (Roger), pozivajući se i na druge autore, konstatuju da je „vremenom ... postajalo sve šire

${ }^{28}$ Budući da se radi o složenom pitanju koje prevazilazi okvire ovog rada, ovde se ograničavamo na sadržaj pojma "životna sredina” koji proističe iz normi sadržanih u međunarodnim ugovorima u oblasti životne sredine.

${ }^{29}$ Harro van Asselt, "The Role of Non-State Actors in Reviewing Ambition, Implementation, and Compliance under the Paris Agreement", Climate Law, Vol. 6, No. 1-2, 2016, p. 94. Autor, pozivajući se na druge autore, ulogu ovih subjekata razmatra u kontekstu različitih konkretnih aktivnosti (kao stručni savetnici, prilikom sprovođenje propisa ili partneri u sprovođenju propisa, kao lobisti, prilikom utvrđivanje dnevnog reda, itd).

${ }^{30}$ W. Jonathan Kuyper, Björn Ola Linnér, and Heike Schroeder, "Non-state actors in hybrid global climate governance: justice, legitimacy, and effectiveness in a post-Paris era", WIREs Clim Change, Vol. 9, No. 1, 2018, p.1.

${ }^{31}$ Jessica F. Green, "Transnational delegation in global environmental governance: When do non-state actors govern?", Regulation \& Governance, Vol. 12, No. 2, 2018, p. 264. 
prihvaćeno da su gradovi, grupe civilnog društva, multinacionalne korporacije i drugi postali deo dinamične 'osnove' transnacionalnih inicijativa za upravljanje klimom.” ${ }^{32}$ Onil (O'Neill), pored „nacionalnih država" ispituje još četiri vrste glavnih aktera u međunarodnim odnosima: međunarodne organizacije, globalne-ekološke pokrete, korporativni sektor i stručne grupe. ${ }^{33}$

E) Jedno od pitanja koje zaslužuje posebnu raspravu (pored pitanja koji subjekti se mogu smatrati "nedržavnim” za potrebe rasprava o upravljanju u oblasti životne sredine) je pitanje uloge koju takvi „akteri” imaju ili bi mogli imati. Naravno, to uveliko zavisi i od toga kako se definišu pojmovi kao što su „upravljanje zaštitom životne sredine”, upravljanje u oblasti životne sredine" ${ }^{\prime \prime}$ itd..$^{34}$ Iako ne postoji saglasnost $u$ vezi sa učešćem NDA na međunarodnom nivou, bar u delu koji se tiče „klasičnog međunarodnog prava”, jednu od formi učešća nedržavnih aktera $u$ aktivnostima koje se tiču životne sredine predstavlja učešće $u$ donošenju odluka koje se tiču životne sredine. ${ }^{35}$

${ }^{32}$ David Held, and Charles Roger, op. cit., p. 533.

${ }^{33}$ Kate O'Neill, The Environment and International Relations, Cambridge University Press, 2009, p. 48. i dalje.

${ }^{34}$ Detaljnija rasprava o ovom pitanju izlazi iz okvira rada, ali se nikako ne bi mogla ignorisati njegova relevantnost za izvođenje preciznijih zaključaka. Za različite pristupe ovom pitanju videti, npr: Frank Biermann and Philipp Pattberg, op. cit. p. 278; Andrew Hargrove, Mais Qandeel, Jamie M. Sommer, "Global governance for climate justice: A cross-national analysis of CO2 Emissions", Global Transitions, No. 1, 2019, p. 195; McKenzie F. Johnson, "Strong (green) institutions in weak states: Environmental governance, and human (in)security in the Global South", World Development, Vol. 122, 2019, pp. 433-445; Matthew Himley, "Geographies of Environmental Governance: The Nexus of Nature and Neoliberalism", Geography Compass, Vol. 2, No. 2, 2008, pp. 433-451; Steven Bernstein and Benjamin Cashore, "Complex global governance and domestic policies: four pathways of influence", International Affairs, Vol. 88, No. 3, 2012, pp. 585-604.

${ }^{35}$ Pitanje razlikovanja aktivnosti koje NDA sprovode na nacionalnom nivou od onih koje prevazilaze okvire granica jedne države jeste praktično pitanje metodološkog karaktera koje bi moglo da komplikuje analizu. Za potrebe ovog rada ne ulazi se u posebnu raspravu o ovom pitanju, polazeći od pretpostavke o unverzalnosti pojedinih problema u oblasti životne sredine i prirodnih resursa (dobara) koji se štite međunarodnim ugovorima $u$ oblasti životne sredine. Noramtivno 
Ako bi se Konvencija o dostupnosti informacija, učešću javnosti u donošenju odluka i pravu na pravnu zaštitu u pitanjima životne sredine (Arhus, 1998) uzela za osnov, onda bi se moglo govoriti o nekoliko različitih procesa u čijim okvirima je uloga ,javnosti", tj. udruženja građana relativno prepoznatljivo regulisana. ${ }^{36}$ (Članom 2. je propisano da se pod pojmom ,,javnost" smatra ,,jedno ili više fizičkih i pravnih lica i, u skladu sa nacionalnim zakonodavstvom ili praksom, njihova udruženja, organizacije ili grupe" (st. 4). Istovremeno, značaj Arhuske konvencije proističe i iz činjenice da je ovim ugovorom propisano da će svaka Strana „promovisati primenu principa ove konvencije $u$ međunarodnim procesima donošenja odluka u oblasti životne sredine i u okviru međunarodnih organizacija po pitanjima vezanim za životnu sredinu" (čl. 3. st. 7). ${ }^{37}$

posmatrano, prevazilaženju granica između „nacionalnog” i „zajedničkog” („opšteg" u smislu „međunarodnog”) doprinosi i pristup na kojem su zasnovana rešenja iz Arhuske konvecnije. Arhuska konvencija se čini prikladnom da se uzme za kriterijum zbog činjence da se „udruženja, organizacije ili grupe”, odnosno „nevladine organizacije koje promovišu zaštitu životne sredine ...”, mogu smatrati glavnim beneficijarom onoga što Konvencija propisuje. Iako po svom karakteru takva udruženja ne moraju biti međunarodna, njihov međunarodni karakter nije isključen. Za šire o „kosmopolitizmu” koji zagovara Ahruhska konvencija videti: Duncan Weaver, „The Aarhus convention and process cosmopolitanism", Int Environ Agreements, Vol. 18, No. 2, 2018, pp. 199-213.

${ }^{36}$ To su: učešće javnosti u donošenju odluka kada su u pitanju posebne aktivnosti koje Arhuska konvencija u Aneksu I nabraja; učešće javnosti u donošenju odluka o aktivnostima koje nisu navedene Aneksu I uz Konvneciju ali na koje se mogu primenjivati pravila Konvencije; učešće javnosti u donošenju odluka kada se radi o aktivnostima koje se ponovo razmatraju ili menjaju i mogu uticati na životnu sredinu; učešće javnosti u donošenju odluka o tome da li da se odobri namerno ispuštanje genetički modifikovanih organizama u životnu sredinu; učešće javnosti u izradi planova, programa i politika koje se tiču životne sredine i učešće javnosti $\mathrm{u}$ toku pripreme izvršnih propisa i/ili opšte primenjivih pravno obavezujućih normativnih instrumenata.

${ }^{37}$ Ovde bi se moglo postaviti pitanje šta se tačno podrazumeva pod „principima ove konvencije" budući da međunarodni ugovor ne sadrži eksplicitne odredbe kojima se definišu principi, kako to čine neki drugi međunarondi ugovori u ovoj oblasti. Umesto toga, Arhuska konvencija već u prve dve alineje preambule "podseća” na 1. princip Stokholmske deklaracije o čovekovoj sredini, i 10. princip Deklaracije o životnoj sredini i razvoju iz Rija (1992). 
f) Imajući u vidu prethodne napomene, u ovom radu se raspravlja o načinu kako se međunarodni ugovori u oblasti životne sredine odnose prema pitanju uloge NDA i to pre svega nevladinih organizacija $u$ sprovođenju aktivnosti koje su propisane ovim međunarodnim ugovorima. ${ }^{38}$ Posebno se sagledava pitanje mogućnosti učešća javnosti (kao „nedržavnog aktera”) u kreiranju politike i sprovođenju mera u oblasti životne sredine, na osnovama onoga što je propisano međunarodnim ugovorima $\mathrm{u}$ ovoj oblasti. ${ }^{39}$ Standardi propisani Arhuskom konvencijom (u delu koji se odnosi na pristup informacijama i učešće javnosti) se uzimaju kao polazna osnova za procenu načina kako se međunarodni ugovori u oblasti životne sredine odnose prema pitanju učešća javnosti, za čijeg glavnog nosioca se proglašavaju organizacije građana.

\section{SISTEM UPRAVLJANJA U OBLASTI ŽIVOTNE SREDINE I NDA}

U najširem smislu, i imajući u vidu preovlađujuće karakteristike problema u oblasti životne sredine, ili načina kako se oni razumeju ("globalni značaj", „opšte dobro", ,zajedničko dobro", itd), obično se UN sa svojim regionalnim komisijama obično uzima za osnovu (platformu) koja se koristi za globalno upravljanje i donošenje odluka u oblasti životne sredine. U okviru sistema UN formiran je značajan broj međunarodnih organizacija koje se bave različitim pitanjima u oblasti životne sredine ili povezanim sa životnom sredinom. Jedan broj organizacija deluje samostalnije, van sistema UN. Zbog uočenih problema $\mathrm{u}$ funkcionisanju ovako složenog sistema, pitanje reforme sistema upravljanja je već duži niz godina predmet posebnih rasprava. ${ }^{40}$

${ }^{38}$ Pitanje kriterijuma za odabir međunarodnih ugovora može biti predmet rasprave. Za potrebe ove analize uzeti su ključni međunarodni ugovori globalnog i regionalnog karaktera koji su od značaja za Republiku Srbiju (RS).

${ }^{39}$ Učešće javnosti se uzima kao jedan od najznačajnijih elemenata savremenog koncepta upravljanja u oblasti životne sredine.

${ }^{40} \mathrm{Za}$ šire videti: Frank Biermann, Olwen Davies, Nicolien van der Grijp, "Environmental policy integration and the architecture of global environmental 
Nezadovoljstvo postojećim načinom upravljanja, stanjem životne sredine i rezultatima koji su ostvareni u dosadašnjim aktivnostima u oblasti životne sredine predmet je različitih objašnjenja i kritičkih analiza. ${ }^{41}$ Preispitivanje postojećih modela upravljanja u oblasti životne sredine usmereno je $\mathrm{u}$ više pravaca.

Na primeru klimatskih promena, kao globalnog problema, mogu se sagledavati složenost i osnovni elementi sistema upravljanja i u svim drugim oblastima koja imaju globalni karakter i koje se povezuju sa problemima $u$ oblasti životne sredine.$^{42} \mathrm{U}$ oblasti klimatskih promena se za „široko postavljenu pretpostavku” uzima procena „da pojava transnacionalnih aranžmana upravljanja generiše opštu promenu vlasti s međuvladinog nivoa na poddržavne i nedržavne aktere." ${ }^{43} \mathrm{U}$ takvim okolnostima usklađivanje odnosa između "nacionalnog" i međunarodnih, univerzalnih, tj. opštih ciljeva može da predstavlja izuzetno komplikovano pitanje. ${ }^{44}$ Ovo naročito imajući u vidu da međunarodni ugovori predstavljaju osnovu postojeće arhitekture

governance", Int Environ Agreements, Vol. 9, 2009, pp. 351-369. Marjanneke J. Vijge, "The promise of new institutionalism: explaining the absence of a World or United Nations Environment Organisation", Int Environ Agreements, Vol. 13, No. 2, 2013, pp. 153-176. Maria Ivanova, "Institutional design and UNEP reform: Historical insights on form, function and financing" , International Affairs, Vol. 88, No. 3, 2012, pp. 565-584. Dragoljub Todić, Klimatske promene u pravu i reforma sistema upravljanja, Institut za međunarodnu politiku i privredu, Beograd, 2014.

${ }^{41}$ Za šire videti: Radoslav S Dimitrov, "Empty Institutions in Global Environmental Politics", International Studies Review, No. 0, 2019, pp. 1-25. Orang R. Young., Olav S. Stokke, "Why is it hard to solve environmental problems? The perils of institutional reductionism and institutional overload", Int Environ Agreements , Vol. 20, No. 1, 2020, pp. 5-19.

42 Za šire videti: Lukas Hermwille, "Making initiatives resonate: how can non $\square$ state initiatives advance national contributions under the UNFCCC?", Int Environ Agreements, Vol. 18, No. 3, 2018, pp. 447-466.

${ }^{43}$ Thomas Hickmann, "The Reconfiguration of Authority in Global Climate Governance", International Studies Review, Vol. 19, No. 3, September 2017, p. 432.

${ }^{44} \mathrm{Za}$ neke naznake o ovim pitanjima na primeru primene mera adaptacije na klimatske promene videti: Magnus Benzie, Asa Persson, “Governing borderless climate risks: moving beyond the territorial framing of adaptation", Int Environ Agreements, Vol. 19, No. 4-5, 2019, pp. 369-393. 
institucija upravljanja $\mathrm{u}$ oblasti životne sredine uz nedvosmislenu potvrdu statusa država kao ključnih subjekata. ${ }^{45}$ Pored međunarodnog ugovora kojim se uspostavljaju pravne osnove, Konferencija strana (međunarodnog ugovora) ima karakter centralnog subjekta koji ima određena prava i obaveze (u operacionalizaciji onih prava obaveza koje propisuje ugovor). Tehničke aktivnosti obavljaju sekretarijati međunarodnih ugovora, ali ovi "tehnički" poslovi ponekad mogu da prevaziđu čisto „tehnički” karakter. ${ }^{46}$ Ovome bi trebalo dodati i različita pomoćna tela koja se formiraju $u$ procesu realizacije ciljeva međunarodnih ugovora. Međutim, procenjuje se da je uloga ovih tela „primarno državocentrična” budući da ona odražavaju uvek, čak i kada se predstavljaju kao isključivo stručna („,stručna”), pozicije država koje su članice međunarodnog ugovora, odnosno pomoćnih tela koja su formirana na osnovu tog međunarodnog ugovora. Unutar strukture upravljanja ustanovljene nekim međunarodnim ugovorom formiraju se, često sa jasno suprostavljenim interesima, grupacije pojedinih država (zemalja u razvoju, nerazvijenih, malih ostrvskih, itd). Uloga nevladinih organizacija, privrednih i drugih subjekata ostaje u senci, iako njihove predstavnike države mogu uključiti u zvanične državne delegacije. Formalno takve organizacije možda nemaju glasačko pravo. Međutim, vladine delegacije ih ponekad registruju kao diplomate, gde se mogu uključiti u razmenu informacija i pružanje savete vladama u vezi s procenama stanja stvari u određenoj oblasti, predlaganjem i usvajanjem mera, itd. ${ }^{47}$ Dakle, uloga NDA je marginalizovana i ovi subjekti nemaju jasan položaj, osim tamo gde se pojavljuju (na različite načine) sa državom povezani subjekti. Otuda pitanje statusa „nevladinih” aktera u

${ }^{45}$ Za šire videti: Dragoljub Todić, Ujedinjene nacije i međunarodni ugovori u oblasti životne sredine, Institut za međunarodnu politiku i privredu, Beograd, 2018.

${ }^{46}$ Za šire videti: Thomas Hickmann, Joshua P. Elsässer, "New alliances in global environmental governance: how intergovernmental treaty secretariats interact with non-state actors to address transboundary environmental problems", Int Environ Agreements, 2020, pp. 1-23.

${ }^{47}$ Don Charles, "COP 21 and the evolution of climate change governance", Int. J. Green Economics, Vol. 10, Nos. 3-4, 2016, pp. 287-301. 
sistemu međunarodnih organizacija vladinog karaktera može da bude izuzetno značajno. ${ }^{48}$

\section{Nedržavni akteri u međunarodnim ugovorima u oblasti životne sredine i učešće javnosti}

\section{Globalni međunarodni ugovori}

Nekoliko međunarodnih ugovora u oblasti životne sredine (globalnog i regionalnog karaktera) sadrži odredbe koje se na različite načine odnose na ulogu NDA i pojedina pitanja kojima se reguliše pristup informacijama i učešće javnosti, u skladu sa Arhuskom konvencijom. ${ }^{49}$

a) Članstvo u Okvirnoj konvenciji UN o promeni klime rezervisano je za države članice OUN ili bilo koje od njenih specijalizovanih agencija ili države članice Statuta Međunarodnog suda i regionalnih organizacija za ekonomske integracije (čl. 20, 22, 23)..$^{5}$ Uloga subjekata "nevladinog”

${ }^{48}$ Konsultativni status pruža nevladinim organizacijama, između ostalog, pristup ne samo ECOSOC-u, već i mnogim njegovim pomoćnim telima. Trenutno 4.045 nevladinih organizacija ima konsultativni status. https:/ / www.un.org/develop ment/desa/dspd/civil-society/ecosoc-status.html, 15.08.2020. Za listu organizacija videti: UN, Economic and Social Council, List of non-governmental organizations in consultative status with the Economic and Social Council as of 1 September 2018. E/2018/INF/5. https://undocs.org/E/2018/INF/5, 15.08.2020.

${ }^{49}$ Naravno, domašaj svakog od njih bi trebalo tumačiti u širem kontekstu i pojedinačno u zavisnosti od teritorijalne i materijalne primenjivosti ugovora. Za detaljniju analizu bi bilo posebno značajno definisanje kriterijuma za vrednovanje karaktera prakse da međunarodni ugovori sadrže norme koje sadrži Arhuska konvencija, ili koje liče na norme iz Arhuske konvencije (bar prima facie, prema predmetu regulisanja i načinu kako se to čini). Osim analize mogućih vrednosnih elemenata, posbno bi moglo biti interesantno utvrđivanje kriterijuma za ocenu efekata takve prakse, u delu koji se odnosi na efikasnost primene pojedinih normi, što zaslužuje znatno više prostora. Ovaj deo članka je, uz određene izmene i dopune, zasnovan na tekstu koji je objavljen u: Dragoljub Todić, Tina Janjatović, "Odnos između arhuske konvencije i drugih međunarodnih ugovora Univerzalni karakter vrednosti i/ili unapređenje efikasnosti u primeni", Pravni život, br. 9, 2015, str. 465-476.

${ }^{50}$ Svaka regionalna organizacija za ekonomske integracije koja postane Strana Konvencije, a da ni jedna od njenih zemalja članica nije Strana, podleže svim 
karaktera povezana je sa izvesnim opštim obavezama i pravima država u odnosu na "nevladine organizacije”, kao i Konferenciju Strana ugovornica u odnosu na „nevladina tela”. Tako je propisana obaveza svih strana da „pružaju podršku i sarađuju u oblasti obrazovanja, obuke kadrova i upoznavanja stanovništva o problemima promene klime i podstiču najšire učešće $\mathrm{u}$ tom procesu, uključujući i nevladine organizacije." (aut. pod) (čl. 4). U okviru nadležnosti „,konferencije strana”, kao najvišeg organa konvencije predviđena je opšta obaveza da redovno razmatra sprovođenje Konvencije i svih drugih odnosnih pravnih instrumenata koje može usvojiti Konferencija Strana (čl. 7. st. 2). U tom cilju ona: „traži i koristi, kad je potrebno, usluge i saradnju od strane nadležnih međunarodnih organizacija i međunarodnih organa i nevladinih tela i koristi informacije koje joj dostavljaju." (aut. pod). Učešće NDA $u$ radu Konferencije strana u svojstvu "posmatrača" zagarantovano je osim "ako se tome ne protivi najmanje jedna trećina prisutnih Strana." 51

Pitanja koja su regulisana u prvom i drugom stubu Arhuske konvencije (pristup informacijama i učešće javnosti) samo su načelno sadržana u Okvirnoj konvenciji UN o promeni klime..$^{52}$ Informisanje javnosti, kao obaveza država članica Konvencije, propisano je zajedno sa „obrazovanjem i obukom kadrova”. Propisuje se obaveza strana da „podstiču i olakšavaju” u skladu sa nacionalnim propisima i „u okviru svojih odgovarajućih mogućnosti" razvoj i ostvarivanje programa obrazovanja i informisanja javnosti o problemima promene klime i njenim uticajima; pristup javnosti informacijama o promeni klime i

obavezama Konvencije. U slučaju takvih organizacija čije su jedna ili više zemalja članica i Strane Konvencije, ta organizacija i njene zemlje članice odlučuju o svojim odgovornostima za ispunjavanje obaveza prema Konvenciji. U takvim slučajevima, organizacija i zemlje članice ne mogu istovremeno da ostvaruju prava koja proističu iz Konvencije (čl. 22. st. 2). Ovakve odredbe o regionalnim organizacijama su neka vrsta modela koji se, uz određene modifikacije, primenjuje u savremenim međunarodnim ugovorima.

${ }^{51}$ Dozvola i učešće posmatrača reguliše se pravilima procedure koja je usvojila Konferencija Strana." (čl. 7.6. Okvirne konvencije UN o promeni klime).

${ }^{52} \mathrm{Za}$ tekst ovog međunarodnog ugovora videti: „Službeni list SRJ - Međunarodni ugovori", broj 2/97). 
njenim uticajima; učešće javnosti u rešavanju problema promene klime i njenih uticaja i priprema adekvatnih mera reagovanja. Istovremeno, države imaju obavezu da "sarađuju i podržavaju, na međunarodnom nivou i, „tamo gde je neophodno, koristeći postojeće organe: i) razradu i razmenu obrazovnog i materijala namenjenog upoznavanju javnosti sa problemima promene klime i njenih uticaja" (aut. pod).

b) Slično kao i Okvirna konvencija o promeni klime, Kjoto protokol propisuje da će Konferencija strana, u svojstvu sastanka Strana ovog Protokola, redovno kontrolisati implementaciju Protokola i u okviru svog mandata donositi odluke neophodne za efikasnost te implementacije. Ona izvršava funkcije koje su joj stavljene u nadležnost Protokolom, i, između ostalog, "traži i koristi, kada je to neophodno, usluge i saradnju, kao i informacije od kompetentnih medunarodnih organizacija $i$ meduvladinih $i$ nevladinih organa (čl. 13). Kjoto Protokol u članu 10. propisuje obavezu država članica da ",sarađuju i podstiču na međunarodnom nivou, ... unapređuju razvoj i implementaciju programa obrazovanja i obuke uključujući sve intenzivnije jačanje nacionalnih kapaciteta", kao i da "omoguće lakše informisanje javnosti na nacionalnom nivou i njen pristup informacijama o promeni klime." (aut. pod).

c) Neki autori procenjuju da Pariski sporazum o klimi omogućava značajniju ulogu NDA, za razliku od Kjoto protokola i Sporazuma iz Kopenhagena. ${ }^{53}$ Učešće u svojstvu "posmatrača” na zasedanjima Konferencije strana, koja istovremeno služi i kao sastanak država potpisnica Sporazuma iz Pariza, zagarantovano je Specijalizovanim agencijama UN i Međunarodnoj agenciji za atomsku energiju. ${ }^{54}$ Zahtev svakog tela ili agencije, bilo nacionalne ili međunarodne, vladine ili nevladine, koja je kvalifikovana za pitanja obuhvaćena Sporazumom i koja je obavestila Sekretarijat o nameri da u svojstvu posmatrača

${ }^{53}$ David Held, and Charles Roger, "Three Models of Global Climate Governance: From Kyoto to Paris and Beyond", Global Policy, Vol. 9, No. 4, 2018, p. 533.

${ }^{54}$ Specijalizovane organizacije i agencije Ujedinjenih nacija podstiču se da podrže napore Strana u sprovođenju mera iz stava 7. ovog člana, uzimajući u obzir odredbe stava 5. ovog člana, koji se odnosi na „osnaženje ... saradnje u oblasti prilagođavanja, uzimajući u obzir Okvir za prilagođavanje iz Kankuna." 
prisustvuje zasedanju Konferencije strana, može biti prihvaćen osim u slučaju da najmanje jedna trećina Strana ne uloži prigovor.

U delu koji se odnosi na sprečavanje i minimiziranje gubitaka i šteta nastalih kao posledica negativnih uticaja promene klime (čl. 8) propisana je obaveza da Varšavski međunarodni mehanizam sarađuje sa „postojećim telima i ekspertskim grupama u okviru Sporazuma, kao i sa relevantnim organizacijama i stručnim telima van Sporazuma." (st. 5). Pariski sporazum direktno upućuje na dva ključna elementa Arhuske konvencije, propisujući obavezu strana ugovornica da „sarađuju na primeni mera, gde je to moguće, kako bi poboljšalie ... uččšć javnosti $i$ pristup javnosti informacijama, ..." (čl. 12) (aut. pod).

d) Konvencija Ujedinjenih nacija o borbi protiv dezertifikacije $u$ zemljama sa teškom sušom i/ili dezertifikacijom, posebno u Africi (Paris, 1994) spominje nevladine organizacije i udruženja ukupno 34 puta i to na različitim mestima: od premabule, preko principa (čl. 3), obaveza ugroženih zemalja (čl. 5), osnovni pristup (čl. 9), nacionalni akcioni program (čl. 10), podrška u izradi i sprovođenju akcionih planova (čl. 13), kooridnacija u izradi akcionih programa (čl. 14), tehnička i naučna saradnja (čl. 16), transfer tehnologija (čl. 18), izvori finansiranja (čl. 20), finansijski mehanizmi (čl. 21), Konferencija strana (čl. 22), itd. Kada govori o „merama podrške podizanju kapaciteta, obrazovanju i jačanju javne svesti Konvencija propisuje obavezu da države "sarađuju” (i preko nadležnih međuvladinih organizacija), kao i sa nevladinim organizacijama u preuzimanju i podržavanju javne svesti i programima obrazovanja u ugroženim i, gde je važno, neugroženim zemljama. ${ }^{55}$

e) U preabuli Konvencije o biološkoj raznovrsnosti (Njujork, 1992) naglašava se "važnost i potreba unapređenja međunarodne, regionalne i globalne saradnje između država i međuvladinih organizacija i nevladinog sektora, radi očuvanja biološke raznovrsnosti i održivog

\footnotetext{
${ }^{55}$ Radi ostvarivanja ovih ciljeva države članice imaju obavezu da (a) sprovode kampanje unapređenja javne svesti; (b) unapređuju stalni pristup javnosti odgovarajućim informacijama, i šire učešće javnosti u aktivnostima obuke i javne svesti; (v) podstiču osnivanje udruženja koja doprinose javnoj svesti; (g) razvijaju i razmenjuju materijale o obrazovanju i javnoj svesti, razmenjuju stručnjake da obučavaju osoblje u ugroženim zemaljama u razvoju, itd.
} 
korišćenja njenih komponenti.” Predviđa se i mogućnost da „bilo koje drugo telo ili agencija, bilo vladino ili nevladino" učestvuje u radu Konferencije strana ugovornica u svojstvu posmatrača, ako se jedna trećina Strana ugovornica tome ne suprotstavi." (čl. 23, st. 5). ${ }^{56}$

Značaj pravila iz prva dva stuba Arhuske konvencije do izvesne mere je naglašen u tri člana Konvencije i to: član 13. javno obrazovanje i svest, član 14. procena uticaja i svođenje negativnih uticaja na minimum, i član 15. razmena informacija. Učešće javnosti se spominje u kontekstu procene uticaja na životnu sredinu gde je propisano da će svaka Strana ugovornica „u meri u kojoj je to izvodljivo i odgovarajuće", između ostalog, ,uvoditi odgovarajuće procedure koje zahtevaju procenu uticaja na životnu sredinu usled predloženih projekata koji će verovatno imati znatne negativne efekte na biološku raznovrsnost $u$ cilju izbegavanja ili svođenja na minimum takvih efekata, i gde je prikladno, dozvoljavanja učešća javnosti u takvim postupcima.

f) Članstvo u Bazelskoj konvenciji o kontroli prekograničnog kretanja opasnih otpada i njihovom odlaganju, (Bazel, 1989) rezervisano je za "države i Namibiju, koju predstavlja Savet Ujedinjenih nacija za Namibiju”, kao i "političke i/ili ekonomske integracione organizacije” (čl. 21, 22, 23). Ujedinjene nacije, njihove specijalizovane agencije, kao i bilo koja država koja nije strana ove Konvencije, mogu biti zastupljeni kao posmatrači na sastancima Konferencije Strana Bazelske konvencije (čl. 15. st. 6). Svako drugo "telo ili agencija, bilo nacionalna ili međunarodna, vladina ili nevladina", koja se bavi pitanjima od značaja za Konvenciju mogu učestvovati kao posmatrači, ako izraze takvu želji i ako se tome ne protivi jedna trećina prisutnih Strana. Konvencija spominje i „nevladine entitete" kada reguliše funkcije Sekretarijata u delu koji se odnosi na pripremanje izveštaja koji treba da budu zasnovani na, između ostalog, i inofrmacijama koje su obezbedili "relevantni međuvladini i nevladini entiteti" (čl. 16. st. 1b). "Javnost" se u Bazelskoj konvenciji spominje jedino kao "javna svest" onda kada se propisuje

\footnotetext{
${ }^{56}$ Uslov je da se radi o telu koju je „kvalifikovano u oblastima vezanim za očuvanje i održivo korišćenje biološke raznovrsnosti” i da je o svojoj želji da bude predstavljeno u svojstvu posmatrača obavestilo Sekretarijat.
} 
obaveza podsticanja saradnje između Strana i nadležnih međunarodnih organizacija, odnosno unapređenja javne svesti, razvoja ispravnog upravljanja opasnim otpadima i drugim otpadima i usvajanja novih tehnologija sa niskim nivoom otpada, „uzimajući u obzir potrebe zemalja u razvoja" (čl. 10. st. 4). Jedna od osnovnih aktivnosti strana ugovornica se odnosi na razmenu informacija (čl. 3, 4, 6, 10, 12, 13, 15, 16, itd), ali pristup javnosti informacijama nije posebno regulisan. ${ }^{57}$

f) Slično kako to čine i neki drugi međunarodni ugovori Stokholmska konvencija o dugotrajnim organskim zagađujućim supstancama (Stokholm, 2001) predviđa mogućnost da nevladine organizacije "kvalifikovane" za pitanja kojima se bavi Konvencija budu primljene kao posmatrač na zasedanjima Konferencije Strana ugovornica, osim ukoliko najmanje jedna trećina prisutnih Potpisnica ne uloži prigovor. (čl. 19. st. 8) ${ }^{58}$ Nevladine organizacije se, odredbama Konvencije, proglašavaju za subjekta čiji se "značajan doprinos" u postizanju smanjenja i/ili eliminisanja emisije i ispuštanja dugotrajnih organskih zagađujućih supstanci prepoznaje (zajedno sa "privatnim sektorom") (al. 14. Preambule). Takođe, predviđena je i razmena informacija Sekretarijata Konvencije sa nevladinim organizacijama, kao i državama članicama i međuvladinim organizacijama. (čl. 9. st. 4). Među propisanim poslovima Konferencije, predviđena je i saradnja "kada je to potrebno" sa „nadležnim međunarodnim organizacijama i međuvladinim i nevladinim organizacijama." (čl. 19. st. 5.b) (aut. pod).

Stokholmska konvencija u članu 4. (registar posebnih izuzetaka) govori o registru koji vodi Sekretarijat i koji ima biti dostupan javnosti. Informisanje javnosti, podizanje svesti i edukacija regulisani su članom 10. koji, između ostalog, predviđa obavezu članica ugovora da „, u skladu sa svojim mogućnostima promovišu i razvijaju" informisanje javnosti o

${ }^{57}$ U slučaju Bazelske konvencije trebalo bi imati u vidu i to da je Arhuska konvencija usvojena značajno nakon Bazelske konvencije, te su pitanja koja se odnose na pristup informacijama i učešće javnosti (na način kako to čini Arhuska konvencija) ostala van fokusa interesovanja.

${ }^{58}$ Istom odredbom je predviđena i mogućnost sticanja statusa posmatrača za Ujedinjene Nacije, specijalizovane agencije Ujedinjenih Nacija i Međunarodnu agenciju za atomsku energiju, kao i svake države koja nije Potpisnica ove Konvencije. 
svim dostupnim informacijama o dugotrajnim organskim zagađujućim supstancama i učešće javnosti u rešavanju pitanja u vezi sa dugotrajnim organskim zagađujućim supstancama i njihovim efektima na zdravlje ljudi i životnu sredinu, itd. U preduzimanju mera koje se odnose na istraživanje, razvoj i monitoring, države članice će, u skladu sa svojim mogućnostima, blagovremeno i redovno pružati na uvid javnosti rezultate svojih istraživačkih i razvojnih aktivnosti, kao i rezultate aktivnosti monitoringa (član 11).

g) Nevladine organizacije se na sličan način spominju i $u$ Roterdamskoj konvenciji o postupku davanja saglasnosti na osnovu prethodnog obaveštenja za određene opasne hemikalije i pesticide $u$ međunarodnoj trgovini (Roterdam, 1998. godine). Konferencija strana ugovornica "sarađuje, gde je to odgovarajuće, sa nadležnim međunarodnim organizacijama i međuvladinim i nevladinim telima" (čl. 18, st. 5). Status „posmatrača” na sastancima Konferencije strana nevladina ,tela ili agencija” mogu steći ako su „kvalifikovana za pitanja koja su predmet Konvencije" i ako obaveste Sekretarijat o svojoj želji da prisustvuju sastancima Konfernecije strana ugovornica (čl. 18. st. 7).$^{59}$

Roterdamska konvencija na nekoliko mesta govori o pristupu informacijama. Članom 14. je predviđeno da će "svaka strana ugovornica, ako je to moguće i u skladu sa ciljem ove Konvencije," da olakšava, između ostalog, i pristup javno dostupnim informacijama o domaćim regulativnim postupcima bitnim za ciljeve ove Konvencije; kao i pristup informacijama drugim stranama ugovornicama, direktno ili preko Sekretarijata, o domaćim postupcima kojim se u značajnoj meri ograničavaju jedna ili više upotreba hemikalije. U delu koji se odnosi na sprovođenje Konvencije (član 15), takođe se govori da su države članice obavezne da obezbede „u najvećoj mogućoj meri" da javnost ima odgovarajući pristup informacijama za rukovanje sa hemikalijom i upravljanje udesom kao i

${ }^{59}$ Sekretarijat, između ostalog, prikuplja i informacije o neželjenim posledicama podnete od drugih strana ugovornica, međunarodnih organizacija, nevladinih organizacija ili drugih relevantnih izvora, nacionalnih ili međunarodnih (Aneks IV uz Konvenciju - Informacije i kriterijumi za unošenje izuzetno opasnih formulacija pesticida u spisak Aneksa III). 
informacije o alternativama koje su bezbednije po ljudsko zdravlje i životnu sredinu od hemikalija sa spiska iz Aneksa III.

h) Članstvo u Konvenciji o pravu neplovidbenih korišćenja međunarodnih vodotoka (Njujork, 1997) je, pored država, rezervisano i za organizacije regionalnih ekonomskih integracija (čl. 35). Nevladine organizacije se spominju jedino $u$ preambuli Konvencije gde se konstatuje "vredan doprinos međunarodnih organizacija, ... kodifikaciji i progresivnom razvoju međunarodnog prava u ovoj oblasti”. „Nadležne međunarodne organizacije" se spominju i u kontekstu obaveza koje propisije Konvencija i koje se tiču „vanredne situacije” (čl. 28). Učešće javnosti se ne spominje u Konvenciji, dok se obavezama država u vezi sa razmenom informacija pridaje poseban značaj.

\section{Regionalni i subregionalni međunarodni ugovori}

a) Članstvo u Konvenciji o zaštiti i korišćenju prekograničnih vodotokova i međunarodnih jezera (Helsinki, 1992) je rezervisano za države članice Ekonomske komisije za Evropu i države sa savetodavnim statusom pri Ekonomskoj komisiji za Evropu, kao i organizacijae za regionalnu ekonomsku integraciju koje je osnovala neka od suverenih država, članica Ekonomske komisije za Evropu (čl. 23, 25, 26). Konvencija ne sadrži posebne odredbe koji bi se odnosile na ulogu nevladinih organizacija. Međutim, principi Arhuske konvencije iz prvog stuba (pristup informacijama) sadržani su u ovom međunarodnom ugovoru. U članu 11. („zajedničko praćenje i procena”) propisuje se obaveza „priobalnih strana” ${ }^{60}$ da „izrađuju i primenjuju zajedničke programe praćenja stanja prekograničnih voda, uključujući velike vode i plivajući led, kao i prekogranične uticaje." U tom kontekstu one imaju obavezu da redovno sprovode "zajedničku ili usklađenu procenu stanja prekograničnih voda i efikasnosti mera za sprečavanje, kontrolu i smanjenje prekograničnog uticaja." Istovremeno, u obavezi su da rezultate ovih ocena učine dostupnim javnosti u skladu sa odredbama

60 „Priobalne strane” su Strane čije se granice nalaze na istim prekograničnim vodama (Član 1. t. 4). 
člana 16. ove konvencije. ${ }^{61}$ Interesantan nivo usklađenosti za zahtevima iz Arhuske konvencije sadržan je u stavu 2. člana 16. koji propisuje da će se „priobalne strane ... postarati da se pomenute informacije stave javnosti na uvid u svakom razumnom momentu bez naknade i da se omogući predstavnicima javnosti dobijanje kopija tih informacija po razumnoj ceni." U delu koji se odnosi na "smernice za razvoj najboljih praksi za životnu sredinu" (Aneks II), predviđeno je da će, prilikom izbora najpogodnije kombinacije mera koje u pojedinačnim slučajevima mogu da čine najbolju praksu za životnu sredinu, biti razmotren niz mera prikazanih po gradaciji, među kojima su i „informisanje i obrazovanje javnosti i korisnika o posledicama izbora pojedinih aktivnosti i proizvoda na životnu sredinu, njihovom korišćenju i krajnjem odlaganju".

b) Protokol o vodi i zdravlju uz Konvenciju o zaštiti i korišćenju prekograničnih vodotokova i međunarodnih jezera (London, 1999) spominje nevladine organizacije samo na jednom mestu, ali na način kojim se formuliše jasna obaveza da na svojim sastancima, strane moraju stalno vršiti pregled sprovođenja ovog protokola. Imajući ovu svrhu na umu one moraju, između ostalog, i da uspostave modalitete za učestvovanje drugih nadležnih međunarodnih vladinih i nevladinih tela na svim sastancima i drugim aktivnostima prikladnim za postizanje svrhe ovog protokola (čl. 16, st. 3f) (aut. pod). ${ }^{62}$ U Protokolu se dostupnost informacijama i učešće javnosti u donošenju odluka koje se odnose na vodu i zdravlje proglašavaju se „potrebnim”, između ostalog da bi se povećao kvalitet i sprovođenje odluka, izgradila svest javnosti o tim pitanjima, da bi se javnosti pružila prilika da izrazi svoja

${ }^{61}$ Ovo se posebno odnosi na sledeće informacije: ciljevi kvaliteta voda; izdate dozvole i uslovi koji se moraju ispuniti; i rezultati uzorkovanja vode i efluenta sprovedenog u okviru praćenja i procena, kao i rezultata provere ispunjenosti ciljeva kvaliteta vode ili uslova iz dozvola.

${ }^{62}$ A cilj Protokola je „podsticati na svim prikladnim nivoima, u nacionalnom kao i u prekograničnom i međunarodnom kontekstu, zaštitu ljudskog zdravlja i dobrobiti, i pojedinačne i zajedničke, u okviru održivoga razvoja, kroz poboljšavanje vodne privrede, što uključuje vodene ekosisteme, te putem prevencije, suzbijanja i smanjivanja prisutnosti bolesti vezanih uz vodu." (čl. 1). 
interesovanja i da bi se omogućilo organima javne vlasti da pravilno uzmu takve interese $\mathrm{u}$ obzir. ${ }^{63}$

c) „Druge relevantne međunarodne organizacije”, pored regionalnih organizacija za ekonomsku integraciju koje su osnovale suverene države članice Ekonomske Komisije za Evropu, se spominju u Konvenciji o prekograničnim efektima industrijskih udesa (Helsinki, 1992) u kontekstu obaveze Konferencije Strana da „u vršenju svojih funkcija, kada smatra odgovarajućim" sa njima sarađuje (čl. 18. st. 3 i 4.). Nevladine organizacije se ne spominju na poseban način kao nosioci izvesnih prava i obaveza. Međutim, principi iz sva tri stuba Arhuske konvencije na izvestan način se spominju u Konvenciji. U članu 9. Konvencije („,obaveštavanje i učešće javnosti”) na relativno uopšten način su sadržana pravila koja se odnose na pristup informacijama, učešće javnosti i pravnu zaštitu. Ugovorne strane imaju obavezu da obezbede da se odgovarajuće informacije daju javnosti u oblastima koje mogu biti pogođene industrijskim udesom koji proističe iz opasne aktivnosti. ${ }^{64}$ Sadržaj informacija propisan je u Aneksu VIII uz Konvenciju. Istovremeno, na neodređen način je propisana obaveza države porekla, strane ugovornice Konvencije, da "kad god je to moguće i odgovarajuće” pruže javnosti „priliku da učestvuje u odgovarajućim postupcima u oblastima koje mogu biti pogođene, sa ciljem da objavi svoje stavove i zabrinutost $\mathrm{u}$ pogledu mera sprečavanja i mera pripravnosti". Javnosti pogođene države se ima „pružiti ista mogućnst” kao i javnosti države strane porekla.

d) Slično kao i kod Konvencije o prekograničnim efektima industrijskih udesa, članstvo u Espo konvenciji o proceni uticaja na životnu sredinu u prekograničnom kontekstu (Espo, 1991) rezervisano je za države članice UNECE i regionalne organizacije za ekonomsku saradnju. „Druge relevantne organizacije” se spominju u kontekstu

${ }^{63}$ Pravila o ,informisanju javnosti” daleko su najdetaljnije regulisana (član 10. i član 9). 64 „Opasna aktivnost” znači bilo koju aktivnost u kojoj je prisutna ili može biti prisutna jedna ili više opasnihmaterija u količinama koje su na kvantitativnoj granici ili prelaze kvantitativnu granicu navedenu u ovde priloženom Aneksu I i koje mogu da prouzrokuju prekogranične efekte (Član 1.b). 
obaveze Konferencije strana ugovornica, dok se nevladine organizacije ne spominju na poseban način. Međutim, centralno pitanje koje reguliše Espo konvencija o proceni uticaja na životnu sredinu u prekograničnom kontekstu u celosti se odnosi na pravila o učešću javnosti u odlučivanju o projektima koji imaju (ili se veruje da imaju) značajan uticaj na životnu sredinu drugih država, osim države gde se neposredno realizuju. ${ }^{65}$ Pravila o saradnji država u realizaciji ovakvih projekata, uključujući i obaveze prema zainteresovanoj javnosti, posebno se razrađuju.

e) Članstvo u Konvenciji o saradnji na zaštiti i održivom korišćenju reke Dunav (Sofija, 1994) je predviđeno za „podunavske zemlje koje su $u$ potpunosti ovlašćene na prava i privilegije članstva u Ujedinjenim nacijama prema Povelji UN, kao i Evropskoj zajednici i drugim regionalnim organizacijama za ekonomsku integraciju na koje su takve države kao njihove članice prenele nadležnosti o pitanjima iz ove konvencije ..." (čl. 25-27). U delu koji se odnosi na istraživanje i razvoj, propisano je da će strane ugovornice „imati u vidu rad ili pomoć odgovarajućih međunarodnih organizacija i agencija u ovim oblastima." (čl. 15. st. 2), a Međunarodna komisija koja se formira Konvencijom, "odlučuje o saradnji sa međunarodnim i nacionalnim organizacijama ili sa drugim telima koja su angažovana ili zainteresovana za zaštitu i upravljanje vodom reke Dunav i voda u slivu ili opšta pitanja zaštite voda i upravljanju vodama." (čl. 18. st. 6). Nevladine organizacije i udruženja se ne spominju kao nosioci posebnih prava i obaveza.

Istovremeno, Konvencija odredbe o informisanju javnosti posebno razrađuje u članu 9. (programi monitoringa) i članu 14. (informisanje za javnost). Formulisana je obaveza da se rezultati monitoringa, kontrole i smanjenja prekograničnog uticaja „prezentuju javnosti kroz odgovarajuće publikacije". U razradi pravila o pristupu informacijama uključena su skoro sva ključna pitanja koja ustanovljava i Arhuska konvencija: obaveza nadležnih institucija da stave na raspolaganje informacije o stanju ili kvalitetu životne sredine bazena Dunava svim ovlašćenim licima što je moguće pre, uz plaćanje razumne nadoknade

${ }^{65}$ To uključuje i relativno detaljno utvrđena pravila o obaveštavanju javnosti u državi gde se realizuju aktivnosti i državi na koju mogu da utiču ove aktivnosti. 
za razuman zahtev; da stavljanje informacija na raspolaganje može biti učinjeno u pisanom, vizuelnom, usmenom obliku ili u formi podataka; obaveza javne ustanove da odgovori osobi koja traži informaciju što je moguće pre i da razlozi za odbijanje pružanja informacije moraju biti pismeno obrazloženi; pravo strane ugovornice da, u skladu sa njenim domaćim pravnim sistemom i primenljivim međunarodnim odredbama, odbije zahtev za informacijama.

f) Okvirni sporazum o slivu reke Save ne spominje na poseban način nevladine organizacije, ali nabraja međunarodne organizacije sa kojima će Strane ugovornice sarađivati u sprovođenju Sporazuma. To su: Međunarodna Komisija za zaštitu reke Dunav (ICPDR); Dunavska Komisija; Ekonomska Komisija za Evropu Ujedinjenih Naroda (UN/ECE); Institucije Evropske Unije. Osim toga, predviđeno je da će Strane sarađivati i sa nacionalnim organizacijama (vlastima ili telima). Savski sporazum „pravoremeno pružanje informacija svim zainteresovanim licima i najširoj javnosti od strane organa nadležnih za primenu ovog sporazuma" propisuje kao obavezu strana ugovornica u delu koji se odnosi na metodologiju "praćenja primene Sporazuma" (član 21).

g) Okvirna konvencija o zaštiti i održivom razvoju Karpata (Kijev, 2003) ulogu nevladinih organizacija reguliše u kontekstu ovlašćenja i dužnosti Konferencije Strana (čl. 14). Predviđeno je da Strane mogu da odluče o mogućnosti pristupa u svojstvu posmatrača na redovnim i vanrednim zasedanjima Konferencije „bilo kojoj nacionalnoj, međuvladinoj ili nevladinoj organizaciji čije aktivnosti su $\mathrm{u}$ vezi sa Konvencijom." (st. 5). Takođe, Konferencija treba da razmatra pitanja od zajedničkog interesa za Strane i da donese odluke neophodne za efikasnu implementaciju Konvencije. Ona, "tamo gde je to primereno”, „uspostavlja saradnju sa kompetentnim telima ili agencijama, bilo nacionalnim ili međunarodnim, vladinim ili nevladinim ..." (st. 2z). Konvencija govori o učešću javnosti kao jednoj od mera koju treba promovisati radi ostvarivanja ciljeva zaštite i održivog razvoja Karpata (član 2). Strane ugovornice se „obavezuju da će voditi politiku koja garantuje učešće javnosti $u$ procesu donošenja odluka u vezi sa 
zaštitom i održivim razvojem Karpata, kao i implementaciju ove Konvencije."66

\section{ZAKLJUČAK}

Iako se u literaturi govori o sve većem značaju NDA u međunarodnim odnosima, analiza pokazuje da ne postoji saglasnost $u$ pogledu ključnih pitanja bitnih za razumevanje njihove uloge i položaja. Najpre se to odnosi na pitanje koji subjekti se mogu smatrati NDA u oblasti životne sredine. Potom, $\mathrm{u}$ literaturi još manje postoji saglasnost $\mathrm{u}$ vezi sa ulogom "nevladinih aktera" u savremenom sistemu upravljanja u oblasti životne sredine. Međutim, kada se govori o međunarodnim ugovorima, koji predstavljaju jedan od osnovnih elemenata strukture sistema upravljanja u oblasti životne sredine, jasno se uočava da su NDA prepoznati kao jedan od subjekata čije je učešće u određenim aktivnostima moguće. Iz analiziranih međunarodnih ugovora (globalnih, regionalnih i subregionalnih) vidi se da uloga NDA $\mathrm{u}$ aktivnostima koje se odnose na upravljanje $\mathrm{u}$ oblasti životne sredine nije precizno definisana, za razliku od uloge nekih međunarodnih vladinih aktera koji imaju konkretnije definisane obaveze i prava. Način kako je formulisana uloga "nedržavnih aktera” ukazuje na to da se može reći da je to daleko je od bilo kakvog sistema u kome bi njihova prava i obaveze (u smislu međunarodnog prava) mogli biti smatrani regulisanim. Međunarodni ugovori u oblasti životne sredine sadrže odredbe opšteg tipa kojima se reguliše uloga aktera „nevladinog” karaktera i, često, samo kao mogućnost da budu konsultovani od strane organa i tela koja koja su formirana relevantnim međunarodnim ugovorima. Dakle, kao pravo organa i drugih tela formiranih međunarodnim ugovorom. Deo međunarodnih ugovora omogućava sticanje statusa posmatrača na sastancima strana ugovornica tih međunarodnih ugovora, ali pod određenim uslovima i uticaja na karakter prava i obaveza koje ugovor propisuje.

${ }^{66}$ Pored toga, što „će voditi politiku koja ima za cilj podizanje ekološke svesti i poboljšanje pristupa javnosti informacijama o zaštiti i održivom razvoju Karpata, kao i promovisanje obrazovnih nastavnih planova i programa..." 
Dva ključna kriterijuma iz Arhuske konvencije (pristup informacijama i učešće javnosti), kao elementi upravljanja u oblasti životne sredine, prepoznati su u jednom delu međunarodnih ugovora u oblasti životne sredine kao obaveze i prava strana ugovornica. Naravno, pri tom bi trebalo imati u vidu i vreme kada su oni usvajani, u odnosu na vreme kada je usvojena Arhuska konvencija koja se sistematizovala ove dve grupe pravila na nivou država iz regiona Ekonomske komisije UN za Evropu. Takva situacija (sa svojom međunarodno-pravnom i unutrašnjepravnom komponentom pristupa informacijama i učešća javnosti u odlučivanju) stvara osnovu da bi se moglo govoriti o izvesnoj pravnoj institucionalizaciji učešća „nevladinih aktera” u aktivnostima koje se tiču životne sredine (unutar država strana ugovornica, ali i u delu koji se odnosi na aktivnosti koje imaju međunarodni karakter). Moguće je da bi se rastući značaj NDA u oblasti životne sredine, o čemu izgleda u literaturi postoji saglasnost, mogao vezivati za njihov potencijalni uticaj na javnost. Ali, od toga pa do zaokruženog sistema prava i obaveza postoji značajan prazan prostor. Iako izgleda da upravljanje u oblasti životne sredine nije moguće bez NDA potencijal njihovog doprinosa je teško proceni na osnovu normi iz međunarodnih ugovora koji ne ostavljaju previše prostora za njihovo delovanje.

\section{LITERATURA}

Alkoby, Asher. "Non-State Actors and the legitimacy of international environmental law", Non-State Actors and International Law, Vol. 3, No. 1, 2003, pp. 23-98.

Alvarez, Jose E. "Are Corporations Subjects of International Law", Santa Clara Journal of International Law, Vol. 9, No. 1, 2011, pp. 1-36.

Bailliet, Cecilia. (Ed). Non-state actors, soft law, and protective regimes: from the margins, Cambridge University Press 2012, p. 6.

Ben-Ari, Rephael Harel. The Normative Position of International NonGovernmental Organizations under International Law, An Analytical Framework, Martinus Nijhoff, Publishers, Leiden, Boston, 2012, p. 47. 
Benzie, Magnus., Persson, Asa. "Governing borderless climate risks: moving beyond the territorial framing of adaptation", Int Environ Agreements, Vol. 19, No. 4-5, 2019, pp. 369-393.

Bernstein, Steven., Cashore, Benjamin. "Complex global governance and domestic policies: four pathways of influence", International Affairs, Vol. 88, No. 3, 2012, pp. 585-604.

Biermann, Frank., Davies, Olwen., van der Grijp, Nicolien. "Environmental policy integration and the architecture of global environmental governance", Int Environ Agreements, Vol. 9, No. 4, 2009, pp. 351-369, DOI 10.1007/s10784-009-9111-0.

Biermann, Frank., Pattberg, Philipp, “Global Environmental Governance: Taking Stock, Moving Forward”, Annu. Rev. Environ. Resour, Vol. 33, No. 1, 2008, p. 280.

Charles, Don. "COP 21 and the evolution of climate change governance", Int. J. Green Economics, Vol. 10, Nos. 3-4, 2016, pp. 287-301.b.

Dick, Katherine. "Exploring the Legal Status of Non-Governmental Organisations under International Energy Treaties", International Community Law Review, Vol. 10, 2008, p. 228.

Dimitrov, S. Radoslav. "Empty Institutions in Global Environmental Politics", International Studies Review, No. 0/2019, pp. 1-25 https://doi.org/10.1093/isr/viz029.

Heiss, Andrew., Johnson, Tana. "Internal, Interactive, and Institutional Factors: A Unified Framework for Understanding International Nongovernmental Organizations", International Studies Review, Vol. 18, No. 3, September 2016, pp. 528-541, https://doi.org/10.1093/ isr/viv014.

Green, F. Jessica. “Transnational delegation in global environmental governance: When do non-state actors govern". Regulation $\mathcal{E}$ Governance, Vol. 12, No. 2, 2018, pp. 264. doi:10.1111/rego.12141.

Hargrove, Andrew., Qandeel, Mais., Sommer, M. Jamie. “Global governance for climate justice: A cross-national analysis of $\mathrm{CO} 2$ Emissions", Global Transitions, No. 1, 2019, p. 195. 
Held, David and Roger, Charles. "Three Models of Global Climate Governance: From Kyoto to Paris and Beyond", Global Policy, Vol. 9, No. 4, 2018, pp. 527-537. doi:10.1111/1758-5899.12617.

Hermwille, Lukas. "Making initiatives resonate: how can non-state initiatives advance national contributions under the UNFCCC?", Int Environ Agreements, Vol. 18, No. 3, 2018, pp. 447-466.

Hickmann, Thomas., Elsässer, Joshua P., "New alliances in global environmental governance: how intergovernmental treaty secretariats interact with non-state actors to address transboundary environmental problems", Int Environ Agreements, 2020, pp. 1-23. https://doi.org/10.1007/s10784-020-09493-5.

Hickmann, Thomas. "The Reconfiguration of Authority in Global Climate Governance", International Studies Review, Vol. 19, No. 3, September 2017, p. 432.

https://www.un.org/development/desa/dspd/civil-society/ecosocstatus.html, 15.08.2020.

Himley, Matthew. "Geographies of Environmental Governance: The Nexus of Nature and Neoliberalism", Geography Compass, Vol. 2, No. 2, 2008, pp. 433-451.

Ivanova, Maria. "Institutional design and UNEP reform: Historical insights on form, function and financing", International Affairs, Vol. 88, No. 3, 2012, pp. 565-584.

Jolić, Tvrtko. „Nedržavni akteri i etika međunarodnih odnosa”, Društvena Istraživanja, Vol. 28 No. 4, 2019, pp. 711-729.

Johnson, F. McKenzie, "Strong (green) institutions in weak states: Environmental governance, and human (in)security in the Global South", World Development, Vol. 122, 2019, pp. 433-445.

Kahler, Miles. "Global Governance: Three Futures", International Studies Review, Vol. 20, 2018, pp. 239-246, doi: 10.1093/isr/viy035.

Kuyper, W. Jonathan, Linnér, Björn-Ola, and Heike Schroeder. "Nonstate actors in hybrid global climate governance: justice, legitimacy, and effectiveness in a post-Paris era", WIREs Clim Change, Vol. 9, No. 12018 , p.1. doi:10.1002/wcc.497. 
Lapaš, Davorin. "Non-governmental entities on the doorstep of 'subjectivity' in international law - A path to new international law?", Zbornik Pravnog Fakulteta u Zagrebu, Vol. 62, No. 5-6, 2012, p. 1759.

Lindblom, Anna-Karin. Non-Governmental Organisations in International Law, Cambridge University Press, 2005, p. 88.

Maisley, Nahuel. “The International Right of Rights? Article 25(a) of the ICCPR as a Human Right to Take Part in International LawMaking", European Journal of International Law, Vol. 28, No. 1, 1 February 2017, pp. 89-113, https://doi.org/10.1093/ejil/chx010.

Nasiritousi, Naghmeh., Hjerpe, Mattias., Linne'r, Bjo“rn-Ola. “The roles of non-state actors in climate change governance: understanding agency through governance profiles", Int Environ Agreements, Vol. 16, No. 1, 2016, pp. 111, i dalje.

O'Neill, Kate. The Environment and International Relations, Cambridge University Press, 2009, p. 48. i dalje.

Parry, Clive., Barker, J. C., \& Grant, J. P. Parry and Grant Encyclopaedic Dictionary of International Law (Vol. 3rd ed). Oxford, Oxford University Press, 2009, p. 584.

Raustiala, Kal. "States, NGOs, and International Environmental Institutions", International Studies Quarterly, Vol. 41, No. 4, December 1997, pp. 719-740, https:// doi.org/10.1111/1468-2478.00064.

Ronit, Karsten, Schneider, Volker (Eds). Private Organisations in Global Politics, Routledge, 2000, p. 11.

Reinalda, Bob (Ed). The Ashgate Research Companion to Non-State Actors, Ashgate, UK, 2011, p. 3.

Roger, Charles., Dauvergne, Peter. "The Rise of Transnational Governance as a Field of Study", International Studies Review, Vol. 18, 2016, p. 417.

Sears, Nathan Alexander. "International Politics in the Age of Existential Threats", Journal of Global Security Studies, 0(0), 2020, pp. 1-23, doi: 10.1093/jogss/ogaa02.

Sending, Ole Jacob., Neumann, Iver B. “Governance to Governmentality: Analyzing NGOs, States, and Power", International Studies Quarterly, 
Vol. 50, No. 3, September 2006, pp. 651-672, https://doi.org/ 10.1111/j.1468-2478.2006.00418.x.

Shaw N. Malcolm, International Law, Fifth edition, Cmabridge University Press, Cambridge, 2003.

Shaw N. Malcolm, International Law, Seventh edition, Cmabridge University Press, Cambridge, 2014.

Szazi, Eduardo. NGOs: Legitimate Subjects of International Law, Leiden University Press, 2012, p. 25. i dalje.

Terhalle, Maximilian. "Transnational Actors and Great Powers during Order Transition", International Studies Perspectives, Vol. 17, No. 3, August 2016, pp. 287-306, https:/ /doi.org/10.1111/insp.12077.

Todić, Dragoljub. "Multilateral Environmental Agreements and EU Integration of Western Balkan States (Status of Bosnia and Herzegovina, Montenegro, Serbia and Croatia in Multilateral Environmental Agreemetns)", European Energy and Environmental Law Review, Vol. 28, No. 1, February 2019, pp. 17-27.

Todić, Dragoljub. Ujedinjene nacije i međunarodni ugovori u oblasti životne sredine, Institut za međunarodnu politiku i privredu, Beograd, 2018. Todić Dragoljub, Janjatović Tina, „Odnos između Arhuske konvencije i drugih međunarodnih ugovora - univerzalni karakter vrednosti i/ili unapređenje efikasnosti u primeni", Pravni život, br. 9, 2015, str. 465-476.

Todić, Dragoljub. Klimatske promene u pravu i reforma sistema upravljanja, Institut za međunarodnu politiku i privredu, Beograd, 2014.

UN, Economic and Social Council, List of non-governmental organizations in consultative status with the Economic and Social Council as of 1 September 2018. E/2018/INF/5. https:/ / undocs.org/E/2018/INF/5, 15.08.2020.

van Asselt, Harro. "The Role of Non-State Actors in Reviewing Ambition, Implementation, and Compliance under the Paris Agreement", Climate Law, Vol. 6, No. 1-2, 2016, pp. 91-108. 
Vijge, J. Marjanneke. “The promise of new institutionalism: explaining the absence of a World or United Nations Environment Organisation", Int Environ Agreements, Vol. 13, No. 2, 2013, pp. 153-176.

Weaver, Duncan. The Aarhus convention and process cosmopolitanism, Int Environ Agreements, Vol. 18, No. 2, 2018, pp. 199-213.

Weiss, Joseph S., Dajian, Zhu., Enríquez, Maria Amélia., May, Peter H., do Nascimento, Elimar Pinheiro., Pengue, Walter A., Schmele, Stanislav. "UN environmental policy: Non-State Actors, trends, and the regulatory role of the state", Journal of Political Ecology Vol. 24. 2017, pp. 1013-1037.

Young, R. Orang., Stokke, S. Olav. Why is it hard to solve environmental problems? The perils of institutional reductionism and institutional overload, Int Environ Agreements , Vol. 20, No. 1, 2020, pp. 5-19. 


\title{
NON-STATE ACTORS AND ENVIRONMENTAL PROTECTION GOVERNANCE
}

\begin{abstract}
The paper reflects on a prevailing (scholarly) attitude that there is a tendency of the growing influence of the so-called non-state actors (NSA) in the creation and implementation of modern environmental policy and law. Attention is drawn to particular methodological dilemmas, including open questions regarding the definition of the term "non-state actors". The role and position of NSAs are considered through an analysis of the place of the non-governmental organizations in the most important international environmental agreements of global and regional character, which are, at the same time, of relevance for the Republic of Serbia (RS). The possibility of participation of "public" and non-governmental organizations is considered as one of the key elements for assessing the role of the NSAs. The norms contained in the relevant international agreements regulating access to information and public participation in environmental decisionmaking have been analysed in accordance with the Aarhus Convention on Access to Information, Public Participation in Decision-Making and Access to Justice in Environmental Matters. The conclusion notes that the position and role of NSAs in international agreements in the field of the environment are regulated only in principle and in an uneven and imprecise manner. Some of the agreements prescribe the possibility for non-governmental organizations to acquire the status of observers in the work of various bodies of individual agreements, as well as the possibility to request certain information from them. Such a situation regarding the norms of international agreements could have an impact on the efficiency of environmental governance and requires a further review of the validity of assertions of the growing influence of NSAs.
\end{abstract}

Keywords: non-state actors, non-governmental organizations, environment, climate change, international agreements, Aarhus Convention, public, access to information. 